\title{
Rehun kokonaisfosforin vähentäminen ja fytaasitason nostaminen (ns. super-dosing) munivilla kanoilla
}

\author{
Petra Tuunainen ${ }^{1)}$, Liisa Keto $^{2)}$, Sini Perttilä3), Jarmo Valaja ${ }^{4)}$ ja Terhi Hemmilä5) \\ ${ }^{1}$ Luonnonvarakeskus, Halolantie 31 A,71750 Maaninka, petra.tuunainen@luke.fi \\ ${ }^{1}$ Luonnonvarakeskus, Tietotie 2 C 4,31600 Jokioinen, liisa.keto@luke.fi \\ ${ }^{1}$ Luonnonvarakeskus, Latokartanonkaari 9,007901 Helsinki,sini.perttila@luke.fi \\ ${ }^{2}$ Helsingin yliopisto, Koetilantie 5,00014 Helsingin yliopisto,jarmo.valaja@helsinki.fi \\ ${ }^{3}$ Rehux Oy, Rehutie 23, 21450 Tarvasjoki, terhi.hemmila@rehux.fi
}

\section{TIIVISTELMÄ}

Siipikarjatuotannossa on tarve tehostaa ravinteiden käyttöä ja vähentää typpi- ja fosforipäästöjä ympäristöön. Tehokkaimpia keinoja tilojen ravinnevirtojen tehostamisessa on ruokinnan täsmentäminen.

Munivien kanojen ruokinta edellyttää suositusten mukaista valkuaisen, fosforin ja kalsiumin saantia, jotta lintujen luusto kehittyy normaalisti, linnut pysyvät terveinä, munan laatu hyvänä ja tuotanto kannattavana. Rehunoptimointia on nykyään kuitenkin tarkennettu. Keskimääräisen kokonaisfosforin pitoisuutta on laskettu ja rehuissa käytetään fytaasia edistämään fosforin hyväksikäyttöä. Rehujen kokonaisfosforipitoisuudet ovat usein jo alhaisemmat kuin ruokintasuosituksissa. Kaupallisten fytaasituotteiden valikoima on laajentunut viime vuosina, mutta niiden optimaalisista ja taloudellisesti kannattavista käyttömääristä yhdessä rehufosforin kanssa on vielä kovin niukasti tutkittua tietoa. Fytaasiannosta voidaan todennäköisesti nostaa jopa kolmin- tai nelinkertaiseksi tavalliseen verrattuna (ns. superdosing). Tällöin käyttökelpoisen fosforin ja kalsiumin pitoisuudet suurenevat fytaasin vaikutuksesta ja rehuihin voidaan lisätä vähemmän fosforia ja kalsiumia rehuaineena.

Tilaseurannassa tavoite oli vähentää kanojen fosforin eritystä. Kokeessa tutkittiin kokonaisfosforin vähentämisen ja fytaasiannoksen suurentamisen vaikutuksia munivien kanojen fosforin eritykseen. Tutkimuksessa verrattiin kontrollirehua, jonka laskennallinen fosforipitoisuus on noin $5 \mathrm{~g} / \mathrm{kg} \mathrm{ka}$ ensimmäisessä rehuvaiheessa ja $4,3 \mathrm{~g} / \mathrm{kg}$ ka toisessa rehuvaiheessa ja fytaasin käyttömäärä on 500 FTU, koerehuun, jossa laskennallisen kokonaisfosforin pitoisuutta laskettiin noin $16 \%$ molempiin rehuvaiheisiin ja fytaasiaktivisuus nostettiin kolminkertaiseksi Quantum Blue 10G- fytaasilla (ns. superdosing).

Koe tehtiin varsinaissuomalaisella kanatilalla. Kanoja (LSL Lite) oli kokeessa aina yhdessä parvessa $32500 \mathrm{kpl}$. Kanat elivät virikehäkeissä. Koe suoritettiin kahdessa osassa. Ensimmäinen parvi oli kokeessa 7.5.2018-6.1.2019 ja toinen parvi 1.4-13.10.2019. Kokeen kokonaiskesto oli 28 vk parvea kohden. Koe koostui neljästä 7 vk:n pituisesta jaksosta, joista kaksi oli koe- ja kaksi kontrollikäsittelyä. Jaksot toistettiin parville käänteisessä järjestyksessä. Lisäksi kokeessa oli kaksi rehuvaihetta. Ensimmäinen rehuvaihe oli 37-57 vk ikäisillä kanoilla ja toinen rehuvaihe 58-71 vk ikäisillä kanoilla. Toiseen rehuvaiheeseen laskettiin rehun kokonaisvalkuais- ja energiapitoisuutta. Kokeessa käytetyt rehut olivat täysrehuja.

Rehunäytteistä analysoitiin rehun laatu, fosforipitoisuus ja fytaasiaktiivisuus, kanojen sontanäytteistä kivennäisaineet ja tuhka. Muna- ja luunäytteistä analysoitiin kivennäisaineet ja luista lisäksi murtolujuus. Kummastakin parvesta kanat myös punnittiin ennalta määritetyistä häkeistä kokeen alussa ja jokaisen jakson jälkeen. Lisäksi tila toimitti kanojen tuotantotietoja (esim. veden kulutus, rehunkulutus, lämpötila, elopaino) analysoitavaksi.

Asiasanat: siipikarja, rehut, päästöjen vähentäminen, lanta, ympäristö 


\section{Johdanto}

Fosfori on välttämätön ravintoaine kanalle ja sitä tarvitaan luiden muodostumiseen, energiaaineenvaihduntaan, solujen rakenteisiin ja munan muodostumiseen. Munivilla kanoilla $80-90 \%$ fosforista on sitoutunut luihin ja muniin (Jing ym. 2018). Munivien kanojen ruokinta edellyttää suositusten (esim. Lohmann Tierzucht 2018) mukaista valkuaisen- ja fosforin saantia, jotta lintujen luusto kehittyy normaalisti, linnut pysyvät terveinä ja tuotanto on kannattavaa (Ahmadi \& Rodehutscord 2012. Eri hybrideillä on havaittu eroja fosforin tarpeessa eri aikaan tuotannossa (Lohmann Tierzucht 2018). Tämä johtuu todennäköisesti jalostuksesta, minkä takia kanoilla on munintahuippu eri tahdissa, mikä taas vaikuttaa niiden rehunkulutukseen ja fosforin tarpeeseen.

Vanhemmilla kanoilla loppumuninnan aikana fosforin tarve pienenee, koska kanojen elopainon kasvu on pysähtynyt ja munantuotanto laskee (Lohmann Tierzucht 2018). Tanskalaisessa tutkimuksessa fosforitasoilla $\left(5,8-4,6 \mathrm{~g} \mathrm{~kg}^{-1}\right)$ rehussa ei havaittu vaikutusta kanojen munintaprosenttiin, munan painoon, rehunkulutukseen, rehunhyötysuhteeseen tai kuolleisuuteen (Lambert ym. 2014). Valaja ja Valkonen (2008) ovat tutkimuksessaan todenneet, että loppumuninnan aikaan (kanojen ikä 49-73 viikkoa) kanojen dieetin kokonaisfosforipitoisuus voidaan laskea jopa $n .3,8 \mathrm{~g} \mathrm{~kg}^{-1}$ ilman, että sillä on epäedullista vaikutusta tuotantotuloksiin. Tämä kuitenkin edellyttää fytaasientsyymin käyttöä. Sama on todettu myös aikaisemmassa muninnan vaiheessa (kanojen ikä 19-35 viikkoa) tehdyssä ruokintakokeessa Tanskassa (Steenfeldt 2014).

Kokonaisfosforin pitoisuutta on viime aikoina laskettu munivien kanojen rehuissa. Rehujen kokonaisfosforipitoisuudet ovat usein jo alhaisemmat kuin ruokintasuosituksissa. Tämä mahdollistaa rehuihin lisättävän fytaasientsyymin käyttö (Ahmadi ja Rodehutscord 2012).

Valtaosa viljan ja valkuaisrehujen fosforista (58-80\%) on sitoutuneena fytiinihappoon fytaatiksi, jolloin se ei suoraan ole käytettävissä sikojen ja siipikarjan elimistössä (Steiner ym. 2007). Rehukasvin fosforipitoisuus ja fosforia sitovan fytiinihapon pitoisuus vaihtelee lajin, lajikkeen, typpija fosforilannoituksen ja kasvukauden olosuhteiden sekä rehukasvin käsittelyn mukaan (Reddy ym. 1989, Steiner ym. 2007). Saastamoinen ym. (1992) mukaan typpi- ja fosforilannoitus ja lämpimät ilmat lisäsivät kauran fytiinihappopitoisuutta, kun taas runsaat sateet vähensivät fytiinihappopitoisuutta (Eurola ym. 2004).

Fytaasi on entsyymi, joka irrottaa fosforia fytaateista. Sitä tuotetaan erilaisten mikrobien avulla. Sioilla ja siipikarjalla ei ole luontaisesti fytaasientsyymitoimintaa, eli niiden omat ruuansulatusentsyymit eivät pysty pilkkomaan fytaateista fosforia eläimen tarpeisiin (Steiner ym. 2007). Siksi fytaasientyymiä lisätään nykyisin lähes kaikkiin sikojen, broilereiden ja kanojen täysrehuihin sekä viljan ja sivutuoterehujen kanssa käytettäviin täydennysrehuihin. Fytaasi parantaa sekä fosforin, että aminohappojen sulavuutta (Keshavartz ja Austic 2004). Matalat valkuaistasot ja fosforipitoisuus rehuissa tavallisesti rajoittavat kanojen tuotantoa ja laskevat niiden painoa. Kun tutkimuksessa käytettiin fytaasia rehuissa, joissa oli matala valkuainen ja fosfori, tuotanto oli jopa parempaa kuin korkealla valkuaispitoisuudella ja fosforipitoisuudella ruokituilla kanoilla. Samoin sonnan kokonaistyppi ja fosfori pienenivät $3 \%$, tuotannon huonontumatta.

Rehuun lisätty ja viljojen sisältämä luontainen fytaasi aktivoituu sian ja siipikarjan mahalaukussa ja irrottaa fosforia fytaateista. Fytiinihapon IP6 hajotessa syntyy hajoamistuotteina IP5, IP4, IP3 ja lopulta IP2 estereitä (AB Vista 2016). IP5, IP4 ja IP3 sitovat ohutsuolessa esim. sinkkiä ja huonontavat valkuaisen sulavuutta. Fytaasiannoksen koko ja fytaasivalmisteen tehokkuus ja rehun prosessointiolosuhteet vaikuttavat fytaasin tehoon irrottaa fosforia fytiinihaposta (Reddy ym. 1989, Igamnazarov ym. 1999, Selle ym. 2009, Slominski 2007). Kaupallisten fytaasituotteiden valikoima on laajentunut viime vuosina, mutta niiden optimaalisista käyttömääristä yhdessä rehufosforin kanssa munivien kanojen ruokinnassa on vielä kovin niukasti tutkittua tietoa. Fytaasiannosta voidaan nostaa jopa kolmin- tai nelinkertaiseksi tavalliseen verrattuna (ns. super-dosing), jotta fytaatin epäedullisten hajoamistuotteiden hajoaminen tehostuu (AB Vista 2016). Fytaasiannos voi olla broilereilla ainakin 1500 FTU ilman tuotannon tai terveyden huonontumista (Walk ym. 2014). 
Kokeessa tutkittiin kokonaisfosforin vähentämisen ja fytaasiannoksen suurentamisen vaikutuksia munivien kanojen fosforin eritykseen. Kokeen tavoitteena oli vähentää kanojen fosforin eritystä. Tutkimuksessa verrattiin kontrollirehua (jossa fosforipitoisuus ja fytaasin käyttömäärä on nykyinen) rehuun, jossa kokonaisfosforin pitoisuutta pyrittiin laskemaan vähintään $10 \%$ tavallisesta ja fytaasiaktivisuus $1300 \mathrm{FTU} \mathrm{kg}^{-1}$ Quantum Blue 10G- fytaasilla (ns. super-dosing).

\section{Materiaalit ja menetelmät}

Koe toteutettiin kumppanuustilalla kahdessa osassa: ensimmäinen osa (parvi 1) 25.6.2018-6.1.2019 ja toinen osa (parvi 2) 1.4.2019-13.10.2019. Yhteen parveen kuului kaiken kaikkiaan 32500 lintua. Kanat elivät noin 50 linnun virikehäkeissä. Kaikki kokeen kanat ovat samaa hybridiä (LSL Lite) ja kaikki kokeen kanat olivat molempien tarkastelujaksojen aikana samanikäisiä (44-72 vk:n ikäisiä). Kumpikin osa koostuivat neljästä $7 \mathrm{vk}$ pituisesta jaksosta, jotka toistettiin molemmille parville käänteisessä järjestyksessä:

1. Parvi: kontrolli, koe, kontrolli (2. rehuvaihe), koe (2. rehuvaihe)

2. Parvi: koe, kontrolli, koe (2. rehuvaihe), kontrolli (2. rehuvaihe)

Kokeen kokonaiskesto oli molemmille parville 28 vk. Kokeessa oli seuraavat koekäsittelyt:

1. Rehutehtaan suosittelema määrä fosforia+ fytaasia (kontrolli)

2. Alennettu fosfori+ käyttösuositusten mukainen Quantum Blue 10G- fytaasia (koekäsittely)

Rehut olivat täysrehuja. Ensimmäinen rehuvaihe oli 44-57 vk ikäisillä kanoilla ja toinen rehuvaihe 58-72 vk ikäisillä kanoilla. Toiseen rehuvaiheeseen laskettiin rehun kokonaisvalkuais- ja energiapitoisuutta.

Jokaisesta tilalle toimitetusta pyrittiin ottamaan rehunäyte, joista analysoitiin ainoastaan yksi koontinäyte per jakso. Jokaisen jakson lopussa, viimeisellä viikolla, kerättiin kanalasta myös sonta- ja munanäytteet. Kanat myös punnittiin ennalta määritetyistä häkeistä $(8 \mathrm{kpl})$ ennen kokeen alkamista sekä aina koejaksojen lopussa. Lisäksi, kokeen osien lopussa kanoista luunäytteitä sekä tilalta saatiin tuotantotietoja molemmista parvista.

Rehunäytteistä analysoitiin Luken Jokioisten laboratoriossa kuiva-aine, tuhka, raakavalkuainen, raakarasva, raakakuitu, kivennäisaineet ja fytaasiaktiivisuus. Sontanäytteistä määritettiin kuiva-aine, tuhka, raakavalkuainen ja kivennäisaineet. Munanäytteistä määritettiin munanlaatu (paino, ominaispaino, valkuaisen, keltuaisen ja kuorien painot, kuoren paksuus ja valkuaisen korkeudesta laskettu Haugh-luku). Munan kuorista otettiin 1 koontinäyte per jakso, joista analysoitiin kuiva-aine, tuhka ja kivennäisaineet. Luista analysoitiin murtolujuus, kuiva-aine, tuhka ja kivennäisaineet. Kumppanuustila toimitti lisäksi molemmista parvista kokeen aikaiset tuotantotiedot (veden kulutus, rehun kulutus, lämpötila, elopaino (kanavaa'an mittaama) ja munantuotanto).

\section{Tulokset}

Kaikkia näytteitä ei ole vielä analysoitu ja tulosten tilastotieteellinen käsittely sekä analysointi ovat kesken. Tuloksista esitetään tässä vain aritmeettinen keskiarvo sekä vaihteluväli (min-max).

Rehut optimoitiin täyttämään kanojen ravinnetarve. Rehujen analysoidut koostumukset on esitetty Taulukossa 1. Kokeessa käytettyjen rehujen koostumukset poikkeavat hieman toisistaan. Myös koe- ja kontrollirehujen koostumukset poikkesivat hieman toisistaan ja raakavalkuainen on hieman liian korkealla tasolla kanojen ikä huomioiden (Lohmann Tierzucht 2018). Toiselle parvelle syötettyjen rehujen kivennäisaineanalyysit eivät ole vielä valmistuneet, joten niiden fosfori- ja kalsiumpitoisuuksia ei ole esitetty. 
Taulukko 1. Kokeessa käytettyjen rehujen analysoidut koostumukset.

\begin{tabular}{lcccccccc}
\hline & \multicolumn{3}{c}{ Rehun koostumus, parvi 1 } & \multicolumn{3}{c}{ Rehun koostumus, parvi 2 } \\
\cline { 2 - 8 } & Kontrolli & Koe & Kontrolli & Koe & Koe & Kontrolli & Koe & Kontrolli \\
& 1 & 1 & 2 & 2 & 1 & 1 & 2 & 2 \\
\cline { 2 - 8 } ikä, vk & $44-50$ & $51-57$ & $65-71$ & $58-64$ & $44-50$ & $51-57$ & $65-71$ & $58-64$ \\
Kuiva-aine, \% & 88.78 & 88.52 & 88.73 & 88.67 & 91.70 & 88.95 & 88.58 & 88.26 \\
g kg $^{-1}$ ka & & & & & & & & \\
Raakavalkuainen & 172.55 & 181.45 & 168.56 & 162.21 & 179.50 & 180.88 & 179.05 & 165.20 \\
Raakarasva & 63.87 & 55.23 & 64.70 & 52.13 & 65.00 & 58.35 & 45.27 & 37.62 \\
Raakakuitu & 55.98 & 44.43 & 54.61 & 44.43 & 61.29 & 56.88 & 58.48 & 44.64 \\
Sokeri & 33.96 & 33.81 & 34.46 & 37.20 & 38.66 & 35.60 & 37.35 & 35.01 \\
Tärkkelys & 416.64 & 427.82 & 393.49 & 460.88 & 389.06 & 435.62 & 459.37 & 482.46 \\
Tuhka & 122.25 & 108.31 & 144.61 & 110.71 & 122.09 & 103.63 & 117.35 & 119.65 \\
Kalsium & 32.50 & 27.60 & 41.40 & 28.60 & & & & \\
Fosfori & 5.77 & 5.68 & 5.30 & 4.66 & & & & 60.26 \\
Fytaasiaktiivisuus & 147.33 & 832.4 & 85.96 & 564.46 & 854.31 & 176.53 & 604.74 \\
FTU kg-1 ka & & & & & & & & 6 \\
\hline
\end{tabular}

Sontanäytteiden analyysien tuloksia ei ole vielä analysoitu tilastollisesti. Arvot ovat vasta alustavia keskiarvoja. Sonnan raakavalkuais- ja fosforipitoisuudet näyttäisivät laskevan koejaksoilla kun taas sonnan kalsiumpitoisuudet päinvastoin näyttäisivät nousevan aina koejaksoilla verrattuna kontrollijaksoihin. Taulukossa 2 esitetyt kalsium- ja fosforipitoisuudet on analysoitu vain ensimmäisen parven sontanäytteistä. Toisen parven näytteiden analysointi on vielä kesken.

Taulukko 2. Koekäsittelyjen vaikutukset kanojen sonnan koostumukseen

\begin{tabular}{lcccc}
\hline & Kontrolli 1 & Koe 1 & Kontrolli 2 & Koe 2 \\
\cline { 2 - 5 } & $24.24(23.28-$ & & & \\
kuiva-aine, \% & $25.77)$ & $27.59(25.49-31.56)$ & $26.83(24.78-29.38)$ & $25.61(23.89-26.75)$ \\
raakavalkuainen, & $325.68(307.75-$ & $308.82(297.64-$ & $354.79(310.98-$ & $327.71(303.51-$ \\
$\mathrm{g} \mathrm{kg}^{-1}$ & $356.41)$ & $319.24)$ & $397.45)$ & $340.03)$ \\
& $51.7(48.20-$ & & & \\
$\mathrm{Ca}, \mathrm{g} \mathrm{kg}^{-1} \mathrm{ka}^{*}$ & $57.90)$ & $56.2(55.50-56.80)$ & $28.7(25.80-33.40)$ & $41.4(36.70-48.10)$ \\
$\mathrm{P}, \mathrm{g} \mathrm{kg}^{-1} \mathrm{ka}^{*}$ & $11.0(9.40-12.60)$ & $9.6(8.77-10.20)$ & $16.3(15.60-16.80)$ & $13.8(-13.50-14.20)$ \\
\hline
\end{tabular}

${ }^{*}$ Huom! Kalsium- ja fosforipitoisuudet on määritetty vain ensimmäisen parven näytteistä. Analyysit ovat vielä kesken toisen parven näytteiden kohdalla.

Koekäsittelyiden vaikutukset kanojen munanlaatuun on esitetty Taulukossa 3 . Taulukossa 3 esitettyjen keskiarvojen perusteella munanpaino nousee hieman aina koejaksolla. Myös keltuaisen osuus munissa nousee, mutta kuoren osuus vastaavasti taas pienenee aina koejaksolla. Munankuoren paksuus myös hieman laskee. Keltuaisen väriin, munien ominaispainoon, Haugh-lukuun tai valkuaisen osuuteen ei koekäsittelyillä näyttäisi olevan vaikutusta.

Tilalta saadun tuotantoaineiston alustavat keskiarvot on esitetty Taulukossa 4. Kanojen kuolleisuuden havaittiin hieman laskevan kokeen toisessa vaiheessa. Vedenkulutus kasvoi koejaksoilla, mutta rehunkulutukseen koekäsittelyillä ei näyttänyt olevan vaikutusta. Rehunkulutus kasvoi ainoastaan hieman kokeen toisessa vaiheessa. Myös tuotantoaineistossa näkyy munanpainon kasvaminen aina koejaksoilla. Munintaprosentti laskee kaiken kaikkiaan kokeen toiseen vaiheeseen siirryttäessä. Koekäsittelyillä ei näyttäisi olevan vaikutusta munintaprosenttiin. Kanojen elopainot mitattiin sekä yksilöpunnituksena (8 ennalta määritetystä häkistä, noin 50 lintua per häkki) että yhdessä häkissä olevan kanavaa'an avulla. Kanavaa'an ja yksilöpunnitusten tuloksista on hiukan eroa. Kanavaa'an mittaamat elopainot nousevat aina koejaksoina, mutta yksilöpunnitusten tulokset eivät ole täysin samaa mieltä. 
Taulukko 3. Molempien parvien munan laatu; keskiarvot ja vaihteluväli (min-max)

\begin{tabular}{lcccc} 
& Kontrolli 1 & Koe 1 & Kontrolli 2 & Koe 2 \\
\cline { 2 - 5 } Munanpaino, g & $64.7(55.77-76.72)$ & $65.6(48.43-77.34)$ & $65.2(54.74-77.64)$ & $65.5(53.97-83.07)$ \\
Keltuaisen väri & $9.2(7.00-11.00)$ & $9.6(8.00-11.00)$ & $9.9(8.00-12.00)$ & $9.7(8.00-11.00)$ \\
Ominaispaino & $1.1(1.06-1.19)$ & $1.1(1.06-2.40)$ & $1.1(1.07-1.10)$ & $1.1(0.99-1.01)$ \\
Haugh-luku, & & & & \\
HU & $86.2(66.08-99.70)$ & $88.0(55.10-101.14)$ & $86.7(37.09-97.9)$ & $86.6(57.10-103.59)$ \\
Valkuais\% & $65.7(41.05-75.39)$ & $65.7(49.31-74.39)$ & $66.7(49.56-73.50)$ & $66.2(48.60-74.95)$ \\
Keltuais\% & $21.0(7.57-35.46)$ & $22.2(13.43-37.86)$ & $20.7(13.73-35.41)$ & $22.5(13.10-39.45)$ \\
Kuori\% & $13.2(8.31-20.55)$ & $12.1(9.93-15.24)$ & $12.7(10.24-15.77)$ & $12.3(8.69-15.72)$ \\
Kuoren & $390.7(327.00-$ & $378.4(275.00-$ & $392.7(329.70-$ & $383.7(284.00-$ \\
paksuus, $\mu \mathrm{m}$ & $469.70)$ & $437.33)$ & $477.33)$ & $471.00)$ \\
\hline
\end{tabular}

Taulukko 4. Koekäsittelyjen vaikutukset kanojen tuotantoon (keskiarvot ja vaihteluväli)

\begin{tabular}{lcccc}
\hline & Kontrolli 1 & Koe 1 & Kontrolli 2 & Koe 2 \\
\cline { 2 - 5 } $\begin{array}{l}\text { Kuolleita, } \\
\text { kpl/vrk }\end{array}$ & $3.2(0.00-12.00)$ & $3.1(0.00-12.00)$ & $2.3(0.00-12.00)$ & $2.5(0.00-14.00)$ \\
Vedenkulutus, & $201.6(168.00-$ & $204.7(162.00-$ & $192.1(165.00-$ & $200.4(173.00-$ \\
l/vrk & $246.00)$ & $230.00)$ & $124.00)$ & $242.00)$ \\
$\begin{array}{l}\text { Rehunkulutus, } \\
\text { g/vrk }\end{array}$ & $109.1(86.00-$ & $109.4(78.00-$ & $112.6(91.00-$ & $111.5(95.00-$ \\
& $146.00)$ & $128.00)$ & $137.00)$ & $129.00)$ \\
Munanpaino, g & $64.8(63.00-66.30)$ & $65.3(63.10-67.70)$ & $65.5(64.00-$ & $67.20)$ \\
& & & $89.1(83.13-$ & $65.9(64.40-67.10)$ \\
Muninta\% & $91.8(83.36-99.80)$ & $92.4(85.38-99.37)$ & $95.18)$ & $88.7(80.09-95.13)$ \\
$\begin{array}{l}\text { Elopaino, } g \\
\text { kanavaa'alla }\end{array}$ & $1637(1499-1771)$ & $1658(1541-1760)$ & $1619(1514-1710)$ & $1635(1547-1725)$ \\
$\begin{array}{l}\text { Elopaino, g } \\
\text { yksilöpunnittu }\end{array}$ & $1785(1676-1905)$ & $1752(1662-1854)$ & $1696(1585-1783)$ & $1777(1676-1871)$ \\
\hline
\end{tabular}

Kanojen luiden ja munan kuorien kivennäisaineanalyysit eivät ole vielä toisen parven kohdalla valmiita, joten ne on jätetty vielä tämän raportin ulkopuolelle.

\section{Tulosten tarkastelu}

Rehujen analysoiduista koostumuksista huomaa, että vaikka eri parvien rehureseptit yritettiin suunnitella samanlaisiksi, silti rehujen koostumukset poikkesivat hieman toisistaan. Tämä johtuu todennäköisesti siitä, että päärehuaineet kuten viljat, olivat eri satoa ja vuoden 2018 sato poikkesi monella tavalla normaalista (SVT 2019 Viljasadon laatu). Vuosi 2018 oli toinen peräkkäinen huono satovuosi Suomen pelloilla ja viljan koostumuksen muutokset (SVT 2019). Myös koe- ja kontrollirehujen toteutuneet ja analysoidut koostumukset poikkesivat hieman toisistaan, vaikka rehut suunniteltiin, niin että ainoastaan fosforin ja fytaasin määrät olisivat erottaneet aina saman vaiheen kontrolli- ja koerehut toisistaan. Koerehuissa raakavalkuainen oli hieman liian korkealla tasolla verrattuna ikävaiheen suosituksiin.

Ensimmäisen parven ensimmäisen vaiheen koerehun fosforipitoisuus jäi suunniteltua korkeammaksi. Useissa tutkimuksissa on viime vuosina havaittu, että fosforipitoisuus voi olla munivilla kanoilla hyvinkin alhainen (Valaja ja Valkonen 2008, Steenfeldt 2014). Ahmadi ja Rodehutscord (2012) useita tutkimuksia yhteen summaavassa meta-analyysissä tultiin siihen tulokseen, että soija-maissipohjaisilla rehuilla, sulavan fosforin määrää voidaan laskea $2.2 \mathrm{~g} \mathrm{~kg}^{-1}$ rehua, ilman fytaasin lisäystä, ilman että munivien kanojen tuotanto huonontui. Lambert ym. (2014) mukaan rehussa $2.6 \mathrm{~g} \mathrm{~kg}^{-1}$ 
sulavaa fosforia riitti hyvin kanojen tarpeeseen ja Jing ym. (2018) tutkimuksessa sulavan fosforin pitoisuus voitiin laskea jopa $1.5 \mathrm{~g} \mathrm{~kg}^{-1}$ rehussa ilman vaikutusta kanojen tuotantoon.

Ensimmäisen parven ensimmäisen vaiheen koerehun fosforipitoisuus ei valitettavasti juuri eroa kontrollirehun fosforipitoisuudesta, joten käsittelyjen välisen eron vaikutus kanojen tuotantoon jäivät todennäköisesti vaatimattomiksi tämän vaiheen osalta. Toisen vaiheen rehuissa kokonaisfosforipitoisuuden muutos on enemmän toivotunlainen. Toisen parven rehujen kivennäisaineanalyysit eivät ole vielä valmistuneet, joten sen fosfori- ja kalsiumpitoisuudet puuttuvat vielä toistaiseksi. Rehujen fytaasiaktiivisuudet ovat halutulla tasolla. Koerehuissa fytaasiaktiivisuudet ovat korkeammat kuin kontrollirehuissa, koska niihin on lisätty Quantum Blue- fytaasia noin kolminkertainen määrä tavanomaiseen tasoon nähden, noin $1300 \mathrm{FTU} \mathrm{kg}^{-1}$.

Valtaosa viljan ja valkuaisrehujen fosforista on sitoutuneena fytiinihappoon fytaattina. Fytiinihapon arvellaan huonontavan rehun sulavuutta ja fytaasin lisääminen rehuun parantaa erityisesti aminohappojen sulavuutta sekä tietysti vapauttaa fosforia fytaateista. Useissa tutkimuksissa on kuitenkin löytynyt aktiivista fytaasia ja fosfataasia siipikarjan suolistosta (Maenz ja Classen 1998, Tamim ym. 2004). Maenz ja Classen (1998) löysivät merkittäviä fytaasi- ja fosfataasiaktivisuuksia broilerien ja munivien kanojen pohjukaissuolesta. Entsyymiaktiivisuus laskee mitä pidemmälle ohutsuolessa kulkeudutaan.

Fytaasin lisääminen lintujen rehuun on nykyään normaali toimintatapa kaikkialla maailmassa. Ahmadi ja Rodehutscord (2012) huomasivat, että kun fytaasia lisättiin rehuun 150, 300 tai 400 FTU $\mathrm{kg}^{-1}$, laskennallisen sulavan fosforin määrään voidaan laskea $1.8 \mathrm{~g} \mathrm{~kg}^{-1}, 1.5 \mathrm{~g} \mathrm{~kg}^{-1}$ tai $1.4 \mathrm{~g} \mathrm{~kg}^{-1}$ rehuissa tuotannon huonontumatta. Cowieson ym. (2017) meta-analyysin mukaan valkuaisen ohutsuolisulavuutta pystytään parantamaan merkittävästi lisäämällä lintujen rehuihin fytaasia $(0.80 \rightarrow 0.84)$. Tarkemmin lysiinin, metioniinin, kystiinin ja treoniinin sulavuudet parantuivat $3.4 \%$, $1.3 \%, 7.2 \%$ ja $6.0 \%$.

Lee ym. (2017) tutkimuksessa fytaasin yliannostelu ns. super-dosing, $1500 \mathrm{FTU} \mathrm{kg}^{-1}$, paransi broilereiden luiden fosforipitoisuutta 6\%:1la, vaikka lintujen rehun sulavan fosforin pitoisuus oli matalalla (starttirehussa 0-21 vrk:n ikäisillä linnuilla $3.2 \mathrm{~g} \mathrm{~kg}^{-1}$ rehua ja kasvatusrehussa 22-42 vrk:n ikäisillä linnuilla $2.2 \mathrm{~g} \mathrm{~kg}^{-1}$ rehua verrattuna kontrollirehun sulavan fosforin pitoisuuksiin $4.8 \mathrm{ja} 3.8 \mathrm{~g}$ $\mathrm{kg}^{-1}$ rehua). Fytaasin yliannostelu myös paransi rehunhyötysuhdetta. Tässä kokeessa Quantum Blue Q10- fytaasia annosteltiin koerehuihin noin $1300 \mathrm{FTU} \mathrm{kg}^{-1}$. Kontrollirehuissa käytettiin tavanomaista fytaasivalmistetta $500 \mathrm{FTU} \mathrm{kg}^{-1}$.

Munanäytteet säilytettiin kylmiössä ja pyrittiin analysoimaan viikon sisällä niiden keräämisestä, mutta se ei aina valitettavasti toteutunut. Munanlaatu kuitenkin pysyi erittäin hyvänä eikä säilytyksen havaittu huonontavan munanlaatua merkittävästi. Kokeessa munanpaino nousi hieman aina koejaksolla. Myös keltuaisen osuus munissa nousi, mutta kuoren osuus vastaavasti taas pieneni aina koejaksolla. Munankuoren paksuus myös hieman laski, joten koejaksolla munanlaatu hieman huononi kontrollijaksoon verrattuna. Keltuaisen väriin, munien ominaispainoon, Haugh-lukuun tai valkuaisen osuuteen ei koekäsittelyillä näyttäisi olevan vaikutusta. Munanpainon nouseminen havaittiin myös tuottajan luovuttamista tuotantoaineistoista. Munintaprosentti laskee kaiken kaikkiaan kokeen toiseen vaiheeseen siirryttäessä, mutta se on normaalia kanojen ikääntyessä (Lohmann Tierzucht 2018). Muuten koekäsittelyillä ei näyttäisi olevan vaikutusta munintaprosenttiin. Kanojen elopainot mitattiin sekä yksilöpunnituksena että yhdessä häkissä olevan kanavaa'an avulla. Kanavaa'an ja yksilöpunnitusten tuloksissa on hiukan eroa. Kanavaakaa ehkä käyttivät enemmän pienemmät kanat tai sitten vain tietyt kanat haluavat istua vaa'an päälle. Kanavaa'an mittaamat elopainot nousevat aina koejaksoina, mutta yksilöpunnitusten tulokset eivät ole täysin samaa mieltä. Hieman kuitenkin näyttäisi, että kanat kasvoivat koejaksojen aikana. Tuloksien käsittely on vielä kuitenkin kesken, eikä niiden mahdollisia tilastollisia eroja ole analysoitu.

Tutkimustulokset rehun fosforin vaikutuksesta munanlaatuun ja kanojen luihin ovat epäjohdonmukaisia. Rajoitetun fosforipitoisuuden on havaittu nostavan munan ominaispainoa ja 
kuoren paksuutta, mikä saattoi johtua rehun kalsiumin paremmasta imeytymisestä ja pidättymisestä (Jing ym. 2018). Kuitenkin Lambert ym. (2014) ei tue näitä havaintoja eikä rehun fosforipitoisuuden ole havaittu vaikuttavan munan laatuun, kuoren kestävyyteen eikä sonnan tai luiden fosfori- ja kalsiumpitoisuuksiin. Myös kalsiumin ja fosforin pidättyminen kanojen muniin ja luihin oli samaa riippumatta rehun kalsium- tai fosforipitoisuuksista (Lambert ym. 2014, Jing ym. 2018). Ristiriitaiset tulokset voivat johtua fosforipitoisuuksien vaihtelusta ja kokeiden kestosta. Rehun valkuais- ja fosforipitoisuudet eivät kuitenkaan saisi ylittää eläinten tarvetta, koska ylimääräinen valkuainen ja fosfori eritetään ulosteen mukana ympäristöön. Fosforin kokonaiseritys pienenee kun rehun fosforinpitoisuutta vähennetään (Jing ym. 2018). Tarkentuneen valkuais- ja kivennäisruokinnan tulokset voidaan nähdä lannan pienempinä typpi- ja fosforipitoisuuksina sekä alentuneena rehukustannuksena.

\section{Johtopäätökset}

Kokeen alustavien tulosten perusteella fosforin vähentäminen ei aiheuttanut merkittäviä muutoksia kanojen tuotantoon, mutta munanlaatu näyttäisi hieman huonontuvan: munat suurenevat ja kuoret ohentuvat. Vanhemmilla kanoilla loppumuninnan aikana fosforin tarve pienenee, koska kanojen kasvu on pysähtynyt ja munantuotanto laskee, mutta rehun fosfori-fytaasiruokinnan muutokset vähäfosforisempaan suuntaan on tehtävä harkiten.

\section{Kiitokset}

Haluamme kiittää kaikkia tutkimuksen suunnitteluun, toteutukseen ja raportointiin liittyviä tahoja. Erityisesti kumppanuustilaa, joka mahdollisti tutkimuksen suorittamisen sekä Luken tutkimusmestaria, Toni Vesalaa, joka vastasi lähes kaikkien munanäytteiden käsittelystä sekä Luken laboratorion työntekijöitä.

Tämän tutkimuksen tekemisen mahdollisti rahoitus Manner-Suomen maaseudun kehittämisohjelmasta 2014-2020, joten haluamme kiittää myös päärahoittajaa sekä osarahoittajia: Hankkija Oy, A-rehu Oy, MTK ry, Suomen siipikarjasäätiö sekä Suomen sikajalostuksen säätiö sekä yhteistyökumppaneitamme: GrainSense Oy, Suomen Sikayrittäjät ry ja Suomen Siipikarjaliitto ry.

\section{Kirjallisuus}

AB Vista 2016. Superdosing: where are the benefits coming from? Viitattu 26.4.2018. https://www.abvista.com/Products/Quantum-Blue/Benefits-of-superdosing.aspx.

Ahmadi, H. \& Rodehutscord, M. 2012. A meta-analysis of responses to dietary nonphytate phosphorus and phytase in laying hens. Poultry Science 91: 2072-2078.

https://doi.org/10.3382/ps.2012-02193

Cowieson, A.J., Ruckebusch, J.-P., Sorbara, J.O.B., Wilson, J.W., Guggenbuhl, P. \& Roos, F.F. 2017. A systematic view on the effect of phytase on ileal amino acid digestibility in broilers. Animal Feed Science and Technology 225: 182-194. https://doi.org/10.1016/j.anifeedsci.2017.01.008

Eurola, M., Kontturi, M. \& Tuuri, H. 2004. Effect of nitrogen fertilisation on the phytic acid, mineral and trace element contents of oats. In: Peltonen-Sainio, P. \& Topi-Hulmi, M. (eds.). Proceedings 7th International Oat Conference. Agrifood Research Reports 51: s. 218.

Igamnazarov, R.P., Tillaeva, Z.E. \& Umarova, G.B. 1999. Effect of metal ions on the activity of extracellular phytase of Bacterium sp. Chemistry of natural compounds 35:661-664.

https://doi.org/10.1007/BF02236298 
Jing, M., Zhao, S., Rogiewicz, A., Slominski, B.A. \& House, J.D. 2018. Assessment of the minimal available phosphorus needs on laying hens: Implications for phosphorus management strategies. Poultry Science 97: 2400-2410. https://doi.org/10.3382/ps/pey057

Keshavartz, K. \& Austic, R.E. 2004. The use of low-protein, low-phosphorus amino acids- and phytase supplemented diets on laying hen performance and nitrogen and phosphorus excretion. Poultry Science 83: 75-83. https://doi.org/10.1093/ps/83.1.75

Lambert, W., van Krimpen, M. \& Star, L. 2014. Phosphorus requirement in laying hens. Report no. 1326-2. Viitattu: 24.4.2018.

https://www.researchgate.net/publication/283274521_Phosphorus_requirement_in_laying_hens.

Lee, S.A., Nagalakshmi, D., Raju, M.V.L.N., Rama Rao, S.V. \& Bedford, M.R. 2017. Effect of phytase superdosing myo-inositol and available phosphorus concentrations on performance and bone mineralisation on broilers. Animal Nutrition 3: 247-251. https://doi.org/10.1016/j.aninu.2017.07.002

Lohmann Tierzucht 2018. Lohmann LSL Lite layers Management guide cage housing. Viitattu 26.4.2018. http://www.ltz.de/de-wAssets/docs/management-guides/en/Cage/White/LTZManagement-Guide-LSL-Lite.pdf.

Maenz, D.D. \& Classen, H.L. 1998. Phytase activity in the small intestine brush border membrane of the chicken. Poultry Sciense 77: 557-563. https://doi.org/10.1093/ps/77.4.557

Reddy, N.R., Pierson, M.D., Sathe, S.K. \& Salunkhe, D.K. 1989. Phytates in Cereals and Legumes, Boca Raton, Florida: CRC Press.

Saastamoinen, M., Plaami, S. \& Kumpulainen, J. 1992. Beta-Glucan and phytic acid content of oats cultivated in Finland, Acta Agriculturae Scandinavica. Section B: Soil and Plant Science 42:6-11. https://doi.org/10.1080/09064719209410193

Selle, P.H., Cowieson, A.J. \& Ravindran, V. 2009. Consequences of calcium interactions with phytate and phytase for poultry and pigs. Livestock Science 124:126-141.

https://doi.org/10.1016/j.livsci.2009.01.006

Slominski, B.A., Davie, T., Nyachoti, M.C. \& Jones, O. 2007. Heat stability of endogenous and microbial phytase during feed pelleting. Livestock Science 109:244-246.

https://doi.org/10.1016/j.livsci.2007.01.124

Steenfeld, S. 2014. Poultry Production and Health PhD-course, Foulum, Denmark.

Steiner, T., Mosenthin, R., Zimmermann, B., Greiner, R. \& Roth, S. 2007. Distribution of phytase activity, total phosphorus and phytate phosphorus in legume seeds, cereals and cereal by-products as influenced by harvest year and cultivar. Animal Feed Science and Technology 133: 320-344. https://doi.org/10.1016/j.anifeedsci.2006.04.007

Suomen virallinen tilasto (SVT): Metsänhoito- ja metsänparannustyöt. Helsinki: Luonnonvarakeskus Viitattu 7.2.2020. https://stat.luke.fi/satotilasto

Tamim, N.M., Angel, R. \& Christman, M. 2004. Influence of dietary calcium and phytase on phytate phosphorus hydrolysis in broiler chickens. Poultry Science 83:1358-1367.

https://doi.org/10.1093/ps/83.8.1358

Valaja, J. \& Valkonen, E. 2008. Munivien kanojen loppumuninnan aikainen fosforiruokinta, MTT.

Walk, C.L., Santos, L.L. \& Bedford, M.L. 2014. Influence of superdoses of a novel microbial phytase on growth performance, tibia ash, and gizzard phytate and inositol in young broilers. Poultry Science 63: 1172-1177. https://doi.org/10.3382/ps.2013-03571

Wilkinson, S.J., Selle, P.H., Bedford, M.R. \& Cowieson, A.J. 2014. Separate feeding of calcium improves performance and nutrient digestibility in broiler chicks. Animal Production Science 54: 172-178. https://doi.org/10.1071/AN12432 